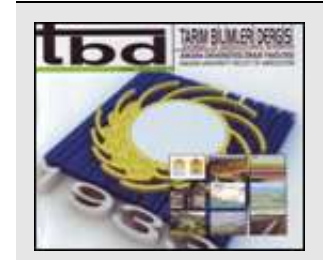

Tarım Bilimleri Dergisi Tar. Bil. Der.

Dergi web sayfasi: www.agri.ankara.edu.tr/dergi
Journal of Agricultural Sciences

Journal homepage:

www.agri.ankara.edu.tr/journal

\title{
The Effect of Sodium Silicate and Methyl Jasmonate on Pigments and Antioxidant Activity of Tomato (Solanum lycopersicum L.) Under Salinity Stress
}

\author{
Hasan ZAMANI ${ }^{a}$, Mohammad Javad ARVIN*b, Abdolhossein Aboutalebi JAHROMíc, Vahid ABDOSSía ${ }^{\mathrm{a}}$, Ali \\ Mohammadi TORKASHVAND ${ }^{\mathrm{a}}$

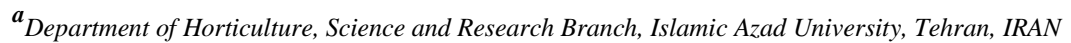 \\ ${ }^{b}$ Department of Horticulture, Shahid Bahonar University of Kerman, Kerman, IRAN \\ ${ }^{c}$ Department of Horticulture, Jahrom Branch, Islamic Azad University, Jahrom, IRAN
}

\section{ARTICLE INFO}

Research Article

Corresponding Author: Mohammad Javad ARVIN, E-mail: mjarvin@uk.ac.ir, Tel: +98 (343) 3776611

Received: 08 May 2019, Received in Revised Form: 20 July 2019, Accepted: 01 August 2019

\section{AUTHORS ORCID ID:}

(Hasan ZAMANI: 0000-0001-5796-2014),(Mohammad Javad ARVIN: 0000-0002-3661-6902), (Abdolhossein Aboutalebi JAHROMI: 00000001-5114-9049),(Vahid ABDOSSİ: 0000-0001-9928-9542), (Ali Mohammadi TORKASHVAND: 0000-0003-4438-9241 )

\begin{abstract}
The present study aimed to investigate the effects of sodium silicate (Si) and methyl jasmonate (MeJA) on the pigments and antioxidant activity of tomato, under salinity stress. For this purpose, completely randomized factorial design with three factors including three levels of salinity $\left(0,4\right.$ and $\left.6 \mathrm{dS} \mathrm{m}^{-1}\right), \mathrm{Si}(0,4$ and $8 \mathrm{mM})$ and MeJA $(0,5$ and $7.5 \mu \mathrm{M})$, and three replications was used. The present study displayed that the increase in salinity level reduced chlorophyll index,
\end{abstract}

fluorescence, and vitamin C; however, the catalase (CAT) and ascorbate peroxidase (APX) activities increased. MeJA and $\mathrm{Si}$ enhanced the chlorophyll index and vitamin $\mathrm{C}$ at different salinity levels, respectively. CAT and APX decreased when the salinized plants were treated with MeJA and Si. MeJA and Si may act to mitigate the adverse effect of salinity stress by reducing the $\mathrm{H}_{2} \mathrm{O}_{2}$ production. Finally, it can be concluded that MeJA and Si partially offset the adverse impacts of salinity stress.

Keywords: Methyl jasmonate, Salinity stress, Sodium silicate, Tomato

\section{Introduction}

(C) Ankara Üniversitesi Ziraat Fakültesi

Nowadays, soil and water salinity are the main obstacles and limitation factors for agriculture development all around the world (Behzadifar et al 2013). Approximately $33 \mathrm{M}$ ha of all agricultural lands (55\%) in Iran are affected by soil and water salinity (Haghighi \& Pessarakli 2013). Salinity is the major environmental stress that adversely affects plant metabolism and growth. Yield reductions caused by salinity occur on an estimated $50 \%$ of all irrigated land worldwide (Panhwar et al 2017). Plants employ various methods and physiological mechanisms to adapt to salinity stress so as to mitigate its adverse impacts (Enteshari \& Jafari 2013; Sheikh Beig Goharrizi et al 2016). The destructive effects of salinity on tomato physiology and biochemistry have been subjected to extensive research (Cuartero \& Fernández-Muñoz 1998; Maggio et al 2007). Jasmonate is one of the most important plant growth regulators which can mitigate the adverse effect of environmental stresses. Methyl jasmonate (MeJA) influences the production of proteins and enzymes through gene regulation (Reinbothe et al 1994; Hao et al 2015; Losvik et al 2018). It, also, affects the production of antioxidants which improves plant resistance to environmental stresses (Akbari et al 2018; Boroomand et al 2018). Furthermore, jasmonate plays a crucial role in defense mechanisms against abiotic stresses such as drought, salinity, and low temperature (Yoon et al 2009; Qiu et al 2014). Salinity stress can significantly disrupt the physiological and biochemical activity of tomato. Methyl Jasmonate (MeJA) alleviates the harmful effects of salinity in tomato plants by inducing biochemical and physiological resistance mechanisms (Manan et al 2016). Under salinity condition, plants produce free radicals such as 
superoxide anion, radical hydroxyl, and peroxides (Enteshari \& Jafari 2013). Silica can reduce the concentration of malondialdehyde under salinity stress, which reflects the role of silica in alleviating lipoid peroxidation (Soylemezoglu et al 2009). Silicon may enhance the antioxidant defense mechanisms through increasing the antioxidant enzymes activities and non-enzymatic antioxidants contents. It may also involve in osmotic adjustment and increase photosynthetic enzymatic activities (Zhu \& Gong 2014). The probable mechanisms for the better growth of the plants exposed to silica under salinity stress may be related to preserving nutrient balance, developing the photosynthetic rate, increasing water uptake and maintaining water in leaves (Kardoni et al 2013). Silica improved the soybean growth through increasing in chlorophyll and gibberellic acid contents under salinity stress (Lee et al 2010). In different parts of Iran, tomato production is limited by a variety of stresses such as salt, drought, cold and heat. To the best of our knowledge, no study to date has studied the effects of simultaneous use of MeJA and sodium silicate ( $\mathrm{Si}$ ) on plants under salinity stress. The present study aimed to investigate the effects of MeJA and Si on pigments and antioxidant activity of tomato under salinity stress.

\section{Material and Methods}

\subsection{Plant material and experimental conditions}

The present study was carried out at a commercial greenhouse in Jahrom, Fars province, Iran, during 2017-2018. The greenhouse conditions were as follows: area of $300 \mathrm{~m}^{2}$, thermostat heating system, fan and pad cooling system, plastic cover, the relative humidity of $67 \pm 3 \%$, and day and night temperatures of $26 \pm 3$ and $17 \pm 2{ }^{\circ} \mathrm{C}$, respectively. The seeds of tomato 'Dafnis' (hybrid F1 made in India with 99\% purity and 94\% germination) were sown on a seed planting tray. The plants were transferred to pots at 5 to 6 leaf stage. The pots were filled by $8 \mathrm{~kg}$ of sand with an in-row and inter-row spacing of 35 and $75 \mathrm{~cm}$, respectively. The results of soil and water analyses were presented in Table 1 . A completely randomized factorial design with three factors including three levels of salinity $\left(0,4\right.$ and $\left.6 \mathrm{dS} \mathrm{m}^{-1}\right), \mathrm{Si}(0,4$ and $8 \mathrm{mM})$ and MeJA (0, 5 and $7.5 \mu \mathrm{M})$, and three replications was used. Two weeks after transplanting, water salinity treatments were manually applied, until the end of the plants' lifespan. The salinity solution was composed of sodium and calcium chloride salts (2:1 ratio). Both Si and MeJA were applied in three times at one, 7 and 15 weeks after transplanting. According to Table 2, the plants were fertigated. Also, chelated iron fertilizer $(350 \mathrm{~g})$ and $0.04 \mathrm{~kg}$ of a mix of trace elements (containing $1.45 \% \mathrm{~B}, 3.2 \% \mathrm{Cu}, 7.5 \% \mathrm{Fe}, 8.15 \% \mathrm{Mn}, 4.6 \% \mathrm{Mo}$, and $4.5 \% \mathrm{Zn}$ ) were dissolved in $500 \mathrm{~L}$ of water and used for plant fertigation. At the end of the experiment, the following characters were measured, vitamin $\mathrm{C}$, chlorophyll index, chlorophyll fluorescence, lycopene content, catalase (CAT) and ascorbate peroxidase (APX) activities.

Table 1- The results of water and soil analyses

\begin{tabular}{|c|c|c|c|c|c|c|c|c|}
\hline \multicolumn{9}{|c|}{ Water analyses } \\
\hline $\begin{array}{l}\mathrm{CO}_{3}^{2-} \\
\mathrm{meq} / \mathrm{L}\end{array}$ & $\begin{array}{l}\mathrm{HCO}_{3}^{-} \\
\mathrm{meq} / \mathrm{L}\end{array}$ & $\begin{array}{l}\mathrm{Cl}^{-} \\
\text {meq/L }\end{array}$ & $\begin{array}{l}\mathrm{SO}_{4}{ }^{2-} \\
\mathrm{meq} / \mathrm{L}\end{array}$ & $\begin{array}{l}\text { Total nions } \\
\mathrm{meq} / \mathrm{L}\end{array}$ & $\begin{array}{l}\mathrm{Ca}^{2+} \\
\mathrm{meq} / \mathrm{L}\end{array}$ & $\begin{array}{l}\mathrm{Mg}^{2+} \\
\mathrm{meq} / \mathrm{L}\end{array}$ & $\begin{array}{l}\mathrm{K}^{+} \\
\mathrm{meq} / \mathrm{L}\end{array}$ & $\begin{array}{l}\text { Total cations } \\
\text { meq/L }\end{array}$ \\
\hline 0.00 & 0.85 & 0.80 & 0.82 & 2.47 & 1.25 & 0.86 & 0.01 & 2.67 \\
\hline $\mathrm{EC} \mu \mathrm{S} / \mathrm{cm}$ & TDS mg/L & $\mathrm{pH}$ & SSP & SAR & $\mathrm{TL} \mathrm{mg} / \mathrm{L}$ & $\mathrm{TA} \mathrm{mg} / \mathrm{L}$ & & \\
\hline 280.00 & 171.38 & 7.35 & 32.21 & 0.91 & 90.00 & 42.50 & & \\
\hline \multicolumn{9}{|c|}{ Soil analyses } \\
\hline $\mathrm{EC} \mu \mathrm{S} / \mathrm{cm}$ & $\mathrm{pH}$ & & TNV & $\mathrm{OC}(\%)$ & $\mathrm{OM}(\%)$ & $\mathrm{TN}(\%)$ & $\mathrm{P}\left(\mathrm{mg} \mathrm{kg}^{-1}\right)$ & $\mathrm{K}^{+}\left(\mathrm{mg} \mathrm{kg}^{-1}\right)$ \\
\hline 798 & 7.25 & & 68.0 & 0.31 & 0.53 & 0.03 & 3.28 & 0.79 \\
\hline Clay (\%) & Silt $(\%)$ & & Sand $(\%)$ & Texture & $\mathrm{Cu}\left(\mathrm{mg} \mathrm{kg}^{-1}\right)$ & $\operatorname{Mn}\left(\mathrm{mg} \mathrm{kg}^{-1}\right)$ & $\mathrm{Fe}\left(\mathrm{mg} \mathrm{kg}^{-1}\right)$ & $\mathrm{Zn}\left(\mathrm{mg} \mathrm{kg}^{-1}\right)$ \\
\hline 13.5 & 9.20 & & 77.3 & Sand & 0.20 & 5.30 & 3.60 & 0.80 \\
\hline
\end{tabular}

Table 2- Fertigation program

\begin{tabular}{|c|c|c|c|c|c|c|c|}
\hline & \multirow{2}{*}{$\begin{array}{l}\text { Fertigation } \\
\text { time } \\
\text { (weeks after } \\
\text { sowing) }\end{array}$} & \multicolumn{6}{|c|}{ Type and composition of fertilizer $\left(\mathrm{mg} / \mathrm{dm}^{3}\right)$ and manufacturing country } \\
\hline & & $\begin{array}{l}\text { Calcium } \\
\text { nitrate } \\
\mathrm{Ca}\left(\mathrm{NO}_{3}\right)_{2}\end{array}$ & $\begin{array}{l}\text { Potassium } \\
\text { nitrate } \\
\mathrm{KNO}_{3}\end{array}$ & $\begin{array}{l}\text { Ammonium } \\
\text { nitrate } \\
\left(\mathrm{NH}_{4}\right)\left(\mathrm{NO}_{3}\right)\end{array}$ & $\begin{array}{l}\text { Mono Ammonium } \\
\text { Phosphate - MAP- } \\
\mathrm{NH}_{4} \mathrm{H}_{2} \mathrm{PO}_{4}\end{array}$ & $\begin{array}{l}\text { Petassium } \\
\text { sulfate } \\
\mathrm{K}_{2} \mathrm{SO}_{4}\end{array}$ & $\begin{array}{l}\text { Magnesium } \\
\text { sulfate } \\
\text { MgSO4 }\end{array}$ \\
\hline \multirow{6}{*}{$\begin{array}{l}\text { Autumn } \\
\text { planting }\end{array}$} & $1-4$ & 15 & 16 & 1.5 & 5.5 & - & 12.5 \\
\hline & $5-8$ & 15 & 16 & & 5.5 & - & 12.5 \\
\hline & $9-10$ & 15 & 16 & & 5.5 & - & 12.5 \\
\hline & $11-12$ & 10 & 11 & & 5.5 & 17 & 12.5 \\
\hline & $13-14$ & 10 & 6 & & 5.5 & 27 & 12.5 \\
\hline & $15-18$ & 10 & 3.5 & & 5.5 & 16.5 & 12.5 \\
\hline \multicolumn{2}{|c|}{$\begin{array}{l}\text { Total consumed } \\
\text { fertilizer }\end{array}$} & 75 & 66.5 & 1.5 & 33 & 60.5 & 75 \\
\hline
\end{tabular}




\subsection{Vitamin $C$}

The vitamin C content was measured using the titration method (Suntornsuk et al 2002). The sample extract (10 mL), distilled water $(20 \mathrm{~mL})$ and $2 \mathrm{~mL}$ of $1 \%$ starch solution were mixed in a $250-\mathrm{mL}$ Erlenmeyer. Then, the content of each Erlenmeyer was titrated with the iodide solution in potassium iodide (KI) until the blue-black color was observed. Vitamin $\mathrm{C}$ content (mg per $100 \mathrm{~g}$ sample) was obtained from the following equation:

Vitamin $\mathrm{C}$ content $=$ volume of solution used for each sample $\times 0.88$

\subsection{Chlorophyll index and fluorescence}

In order to measure the chlorophyll index, four upper developed leaves of each seedling were subjected to a Minolta SPAD-502 chlorophyll meter and the average of three seedlings was recorded for each experimental unit.

The chlorophyll fluorescence was measured by a chlorophyll fluorometer (model OS1-FL, Opti-Sciences, Tyngsboro, MA, USA). The quantum yield of photosystem II (ФPSII) were determined under light conditions by the following equation (Maxwell \& Johnson 2000):

$\Phi$ PSII $=\frac{F_{\mathrm{v}}}{F_{m}}$

Variable fluorescence $\left(F_{v}\right)$ was calculated as $F_{m}-F_{0}$, where, $F_{0}$ and $F_{m}$ stand for minimum and maximum chlorophyll fluorescence, respectively.

\subsection{Lycopene content}

The lycopene content was measured by a spectrophotometer (T80, UV/VIS PG Instruments Ltd) by the standard method. The measurement was performed at $503 \mathrm{~nm}$ in hexane solvent (Choudhary et al 2009). The amount of full-trans lycopene was calculated using the following equation and the specific extinction coefficient (Choudhari \& Ananthanarayan 2007).

Lycopene $\quad(\mathrm{mg})=\frac{A \times d i l \times m l \times 10}{E_{1 \mathrm{~cm}}}$

Where $\mathrm{A}$, dil, $\mathrm{ml}$, and $\mathrm{E}_{1 \mathrm{~cm}}$ were the solution absorbance in a 1-cm cuvette, dilution factor, final volume, and specific extinction coefficient of the sample, respectively. Lycopene extraction efficiency was calculated in mg per $100 \mathrm{~g}$ sample using the following equation:

Yield $\quad(\mathrm{mg} / 100 \quad \mathrm{~g})=\left(\frac{C \times V}{M}\right) \times 100$

Where $\mathrm{C}, \mathrm{V}$, and $\mathrm{M}$ were the extracted lycopene content $(\mathrm{mg})$, the extracted oleoresin volume $(\mathrm{g})$, and the weight of the sample skin or dried waste of tomato, respectively.

\subsection{Antioxidant activity}

For determination of antioxidant activity, samples were ground in liquid nitrogen and homogenized in the reaction solution contained $50 \mathrm{mM}$ phosphate buffer ( $\mathrm{pH} 7.8,0.1 \mathrm{mM} \mathrm{Na}{ }_{2}$ EDTA, $1.5 \%$ (m/v) PVPP and 0.1\% (v/v) Triton X100). Then it was centrifuged at $12000 \mathrm{~g}$ for $10 \mathrm{~min}$ at $4{ }^{\circ} \mathrm{C}$. The supernatant was collected for determination of CAT and APX activities. The CAT activity was measured by calculating $\mathrm{H}_{2} \mathrm{O}_{2}$ absorption decrease at $240 \mathrm{~nm}$. One enzymatic unit of catalase is the amount of enzyme that can decompose $1 \mathrm{mM} \mathrm{H}_{2} \mathrm{O}_{2}$ in one minute (Mazorra et al 2002). Ascorbate peroxidase enzyme activity was calculated by the decrease in absorbance of ascorbate within one min at $290 \mathrm{~nm}$. One enzymatic unit of APX is the amount of enzyme that oxidizes $1 \mathrm{mM}$ ascorbate in $1 \mathrm{~min}$ (Chen et al 2009). Enzyme activity was recorded in terms of enzymatic unit per total protein $(\mathrm{mg})$ content.

\subsection{Statistical analysis}

The study was set up as a completely randomized design, with a factorial arrangement and three replications. The normality of the data was evaluated by the Kolmogorov-Smirnov test with the SPSS 25.0 software (SPSS Inc, Chicago, 
IL, USA). Analysis of variance was performed on the data using Statistical Analysis Sofware (Version 9.1 for Windows; SAS Institute, Cary, NC) and the means were compared by the Tukey test $(\mathrm{P}<0.05)$.

\section{Results and Discussion}

\subsection{Analysis of variance}

The ANOVA demonstrated that there were significant differences among the three levels of salinity for vitamin $\mathrm{C}$ content $(\mathrm{P}<0.01)$, chlorophyll index $(\mathrm{P}<0.05)$ and chlorophyll fluorescence $(\mathrm{P}<0.01)$ characters (Table 3$)$. The simple effect of Si was only significant for chlorophyll fluorescence. Also, the results revealed that the double interactions between MeJA with salinity and MeJA with Si were significant for chlorophyll index $(\mathrm{P}<0.05$ and $\mathrm{P}<0.01$, respectively). In addition, ANOVA showed that the triple interactions among the three factors were significant for lycopene content and CAT and APX activities. According to Wickens and Keppel (2004), when the interaction of factors is significant, then less attention is paid to the main effects and then the main focus will be on the interaction effects.

Table 3- ANOVA of studied traits in tomato treated by Si and MeJA under salinity stress

\begin{tabular}{|c|c|c|c|c|c|c|c|}
\hline \multirow[b]{2}{*}{ S.O.V. } & \multirow[b]{2}{*}{$\mathrm{df}$} & \multicolumn{6}{|c|}{ Mean Squares (M.S.) } \\
\hline & & Vitamin C & $\begin{array}{l}\text { Chlorophyll } \\
\text { index }\end{array}$ & $\begin{array}{l}\text { Chlorophyll } \\
\text { fluorescence }\end{array}$ & $\begin{array}{l}\text { Lycopene } \\
\text { content }\end{array}$ & Catalase activity & $\begin{array}{l}\text { Peroxidase } \\
\text { activity }\end{array}$ \\
\hline Salinity (A) & 2 & $8.81 * *$ & $40.89^{*}$ & $0.012 * *$ & 4.32 & 4899.47 & 18.80 \\
\hline $\mathrm{Na}_{2} \mathrm{SiO}_{3}(\mathrm{~B})$ & 2 & 1.45 & 6.29 & $0.001 *$ & 5.50 & 868.09 & 10.80 \\
\hline $\operatorname{MeJA}(\mathrm{C})$ & 2 & 1.15 & 0.13 & 0.0004 & 1.27 & 759.56 & 8.39 \\
\hline $\mathrm{A} \times \mathrm{B}$ & 4 & $2.61 *$ & 20.95 & 0.0006 & 5.28 & 4969.84 & 14.22 \\
\hline $\mathrm{A} \times \mathrm{C}$ & 4 & 0.59 & $26.00 *$ & 0.0003 & 0.93 & 4128.58 & 10.91 \\
\hline $\mathrm{B} \times \mathrm{C}$ & 4 & 1.57 & $114.57 * *$ & 0.0005 & 4.58 & 2968.55 & 12.72 \\
\hline $\mathrm{A} \times \mathrm{B} \times \mathrm{C}$ & 8 & 1.87 & 4.64 & 0.0005 & $7.51 *$ & $6845.18 * *$ & $65.23^{*}$ \\
\hline Error & 54 & 0.9 & 9.1 & 0.0004 & 3.02 & 2253.21 & 26.82 \\
\hline C.V. $(\%)$ & & 8.9 & 5.83 & 2.53 & 29.02 & 32.5 & 28.3 \\
\hline
\end{tabular}

(*,**; significant at 0.05 and 0.01 levels, respectively)

\subsection{Vitamin $C$}

The results demonstrated that the highest vitamin $\mathrm{C}$ content was observed in the interaction of $0 \mathrm{dS}^{-1}$ salinity with 4 $\mathrm{mM} \mathrm{Si}$ (Figure 1). Also, the results showed that at lower levels of salinity $\left(0\right.$ and $\left.4 \mathrm{dS} \mathrm{m}^{-1}\right), 4 \mathrm{mM} \mathrm{Si}$ was more effective to increase vitamin $\mathrm{C}$ compared to the other Si levels, while at $6 \mathrm{dS} \mathrm{m} \mathrm{m}^{-1}$ of salinity the highest vitamin $\mathrm{C}$ content was obtained at $6 \mathrm{mM} \mathrm{Si}$. The mean values of vitamin $\mathrm{C}$ content in this study were within the range normally in tomato reported by Fontes et al (2004). Stamatakis et al (2003) stated that the amount of vitamin C in the plants was increased due to the application of Si to the nutrient solution. Marodin et al (2016) reported that the amount of vitamin C was increased with increasing $\mathrm{Si}$ doses, however, at the highest level of $\mathrm{Si}$, it was decreased. The role of $\mathrm{Si}$ in metabolic pathways involved in the biosynthesis of vitamin $\mathrm{C}$ is unclear yet.

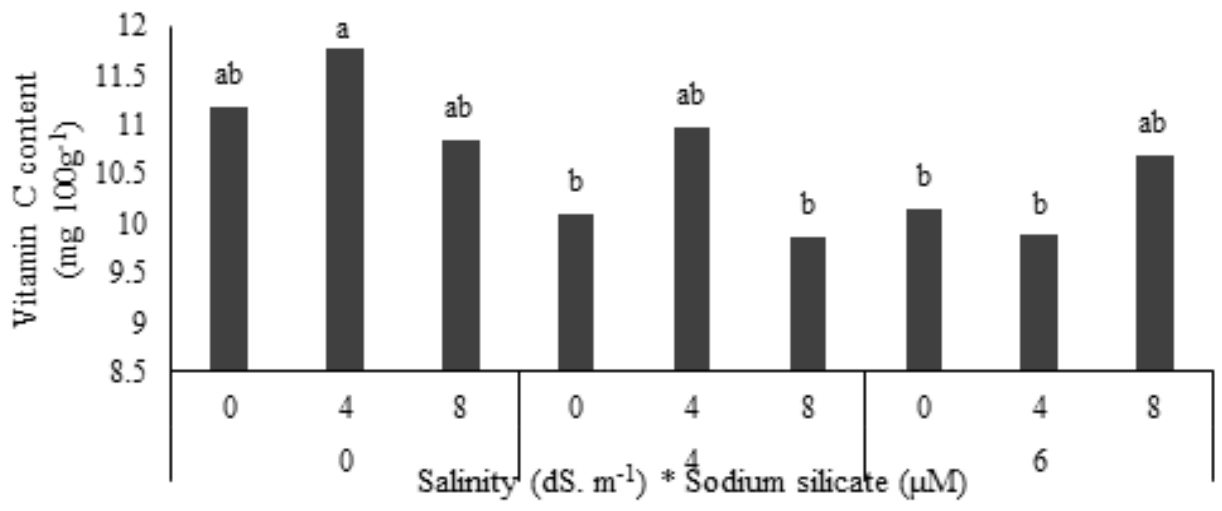

Figure 1- Effect of the interaction between salinity and $\mathrm{Si}$ factors on vitamin $\mathrm{C}$ content of tomato 


\subsection{Chlorophyll index and fluorescence}

According to the results of ANOVA two interactions of the factors including salinity with MeJA and Si with MeJA were significant for chlorophyll index. The interaction between salinity and MeJA showed that with increasing the salinity level from 0 to $6 \mathrm{dS} \mathrm{m}^{-1}$, the chlorophyll index was decreased, however, at 4 and $6 \mathrm{dS} \mathrm{m}^{-1}$ salinity levels, the MeJA enhanced the character (Figure 2a). In addition, the lowest and the highest chlorophyll index were obtained from the interactions of 0 and $4 \mathrm{dS} \mathrm{m}^{-1}$ salinity levels with $7.5 \mu \mathrm{M}$ MeJA, respectively.

The interaction between $\mathrm{Si}$ and MeJA revealed that at $0 \mathrm{mM} \mathrm{Si}$, with increasing in MeJA, the chlorophyll index was increased and then decreased, respectively (Figure $2 \mathrm{~b}$ ), whereas the opposite trend was observed for $4 \mathrm{mM}$ Si with the MeJA levels. Low concentrations of jasmonic acid in Chlorella vulgaris significantly increased the chlorophyll $a$ and $\mathrm{b}$ contents (Czerpak et al 2006). Our results suggested that the effect of MeJA on chlorophyll index was depending on its concentration. Similar results have already been reported (Czerpak et al 2006; Ueda \& Saniewski 2006; Fugate et al 2018). It has been documented that MeJA involved in the expression of a set of genes encoding key enzymes that responsible for chlorophyll biosynthesis via the formation of 5-aminolevulinic acid (Wang et al 2019; Wu et al 2019). MeJA hinders the degradation of chlorophyll and the loss of photosynthesis through activating antioxidant enzymes in the chloroplast, thereby enhancing the growth and activity of the plant (Babst et al 2005).
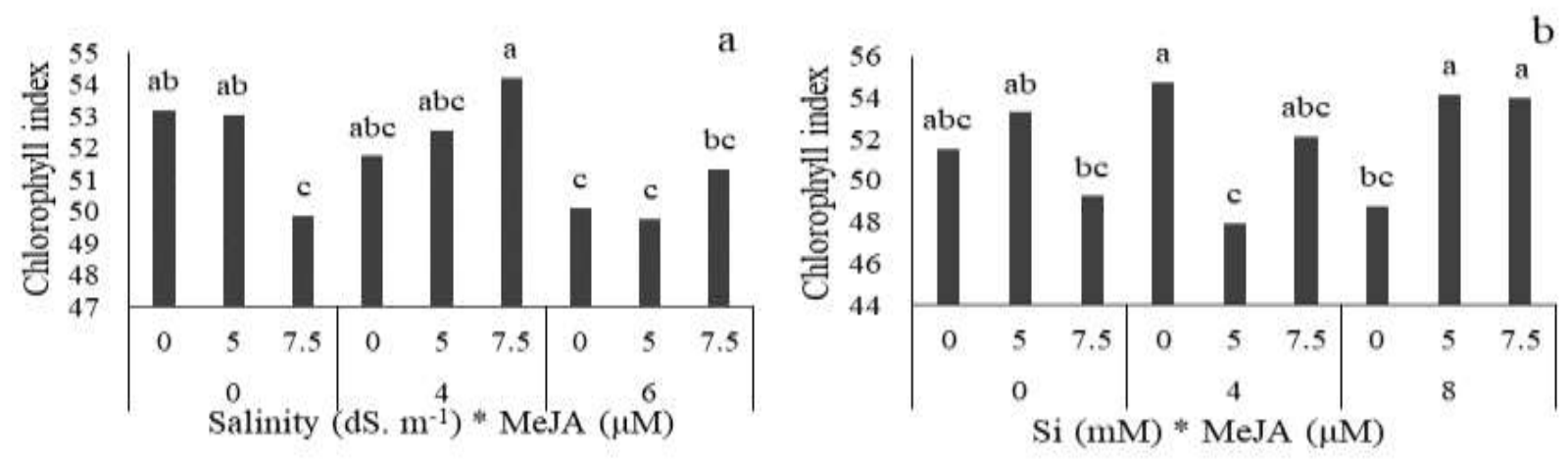

Figure 2- Effect of the interaction between salinity with MeJA (a) and Si with MeJA (b) on chlorophyll index of tomato

The results of ANOVA revealed that the main effects of salinity and Si were significant for chlorophyll fluorescence, while there were no significant effect for the main effect of MeJA and the interactions of the factors. The results also uncovered that the increase in the salinity level resulted in the loss of chlorophyll fluorescence so that the lowest chlorophyll fluorescence was observed at $6 \mathrm{dS} \mathrm{m}^{-1}$ salinity level (0.771; Figure 3a). Similar to salinity levels with increasing in $\mathrm{Si}$ levels the chlorophyll fluorescence was also decreased so that the lowest chlorophyll fluorescence was obtained at $8 \mathrm{mM} \mathrm{Si}(0.775)$, although it was not significant with $4 \mathrm{mM} \mathrm{Si}$ (Figure 3b). Despite that our results showed a reduction in the chlorophyll fluorescence using $\mathrm{Si}$ application, Al-aghabary et al (2005) reported that photochemical efficiency of PSII $\left(\mathrm{F}_{\mathrm{v}} / \mathrm{F}_{\mathrm{m}}\right)$ was enhanced by $\mathrm{Si}$ in tomato under salinity stress. Morales et al (1992) indicated that salinity stress had no significant effect on PSII. However in this study salinity stress significantly decreased the chlorophyll fluorescence. Environmental stresses such as salinity, drought, and heat cause damage to PSII (Rochaix 2011; Mosavi et al 2018).
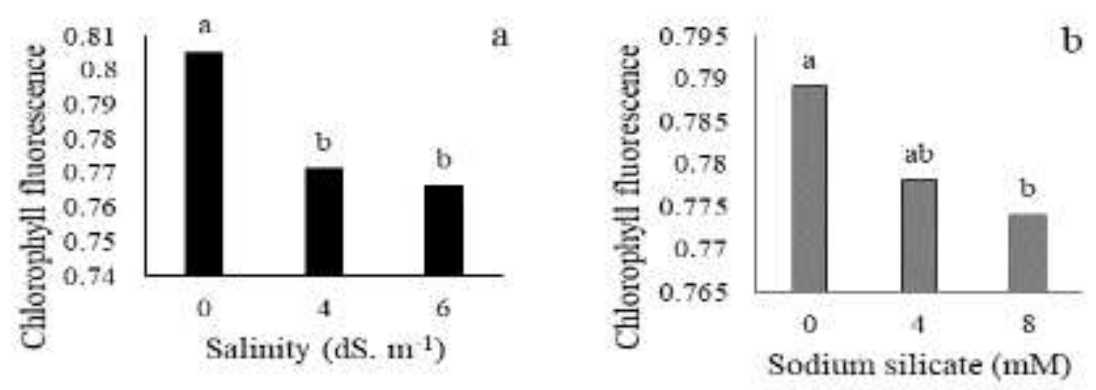

Figure 3- Effect of salinity (a) and $\mathrm{Si}$ (b) on chlorophyll fluorescence of tomato 


\subsection{Lycopene content}

The interaction between the three factors was significant for lycopene content. The results revealed that the highest and lowest lycopene contents were obtained in control $\left(7.98 \mathrm{mg} \mathrm{L}^{-1}\right)$ and $0 \mathrm{mM} \mathrm{Si}$ and $7.5 \mu \mathrm{M} \mathrm{MeJA}$ at $4 \mathrm{dS} \mathrm{m}^{-1}$ salinity $(4.51$ $\mathrm{mg} \mathrm{L}^{-1}$ ) treatments, respectively (Table 4). According to the results, the average values of lycopene content at $0 \mathrm{dS}^{-1}$ salinity with the other factors was more than the other treatments. The salinity stress restricted lycopene content in tomato fruit (Stamatakis et al 2003). Pascale et al (2001) reported that at higher levels of salinity (more than $4 \mathrm{dS} \mathrm{m}^{-1}$ ) the lycopene contents were declined. In the present study a similar result was observed. Based on the results, Si and MeJA had no significant effect on lycopene content. In contrast with our finding Stamatakis et al (2003) and Marodin et al (2016) reported that $\mathrm{Si}$ significantly enhanced lycopene content in tomato. Fruit appearance in tomato is directly related to lycopene content, which the red color of the plant is due to the ratio of lycopene to beta-carotene (Catalkaya \& Kahveci 2019).

Table 4- Effects of the interaction among salinity, Si and MeJA factors on three measured characters of tomato

\begin{tabular}{|c|c|c|c|c|c|}
\hline Salinity $\left(\mathrm{dS} . \mathrm{m}^{-1}\right)$ & $\begin{array}{l}\mathrm{Na}_{2} \mathrm{SiO}_{3} \\
(\mathrm{mM})\end{array}$ & $\begin{array}{l}\text { MeJA } \\
(\mathrm{mM})\end{array}$ & $\begin{array}{l}\text { Lycopene } \\
\left(\mathrm{mg} \mathrm{L}^{-1}\right)\end{array}$ & $\begin{array}{l}\text { Catalase activity } \\
\text { (unit / mg protein) }\end{array}$ & $\begin{array}{l}\text { Peroxidase activity } \\
\text { (unit / mg protein) }\end{array}$ \\
\hline \multirow{10}{*}{0} & \multirow{3}{*}{0} & 0 & $7.98 \mathrm{a}$ & $67.58 \mathrm{c}-\mathrm{f}$ & $9.77 \mathrm{ab}$ \\
\hline & & 5 & $7.66 \mathrm{a}-\mathrm{c}$ & $70.22 \mathrm{c}-\mathrm{f}$ & $12.91 \mathrm{ab}$ \\
\hline & & 7.5 & $5.94 \mathrm{~b}-\mathrm{d}$ & $60.83 \mathrm{~d}-\mathrm{f}$ & $10.32 \mathrm{ab}$ \\
\hline & \multirow{3}{*}{4} & 0 & $6.93 \mathrm{a}-\mathrm{d}$ & $150.59 \mathrm{ab}$ & $10.78 \mathrm{ab}$ \\
\hline & & 5 & $6.16 \mathrm{~b}-\mathrm{d}$ & $75.63 \mathrm{~b}-\mathrm{f}$ & $7.40 \mathrm{ab}$ \\
\hline & & 7.5 & $6.08 \mathrm{~b}-\mathrm{d}$ & $68.53 c-f$ & $7.89 \mathrm{ab}$ \\
\hline & \multirow{3}{*}{8} & 0 & $5.14 \mathrm{~b}-\mathrm{d}$ & 98.98 a-f & $5.66 \mathrm{~b}$ \\
\hline & & 5 & $5.02 \mathrm{~cd}$ & $53.3 \mathrm{~d}-\mathrm{f}$ & $9.91 \mathrm{ab}$ \\
\hline & & 7.5 & $6.28 \mathrm{~b}-\mathrm{d}$ & 109.98 a-e & $10.59 \mathrm{ab}$ \\
\hline & \multirow{3}{*}{0} & 0 & $5.09 \mathrm{~cd}$ & $156.85 \mathrm{a}$ & $10.33 \mathrm{ab}$ \\
\hline \multirow{7}{*}{4} & & 5 & $5.62 \mathrm{~b}-\mathrm{d}$ & $31.2 \mathrm{f}$ & $10.78 \mathrm{ab}$ \\
\hline & & 7.5 & $4.51 \mathrm{~d}$ & $98.14 \mathrm{a}-\mathrm{f}$ & $10.41 \mathrm{ab}$ \\
\hline & \multirow{3}{*}{4} & 0 & $6.38 \mathrm{~b}-\mathrm{d}$ & 90.52 a-f & $10.59 \mathrm{ab}$ \\
\hline & & 5 & $5.88 \mathrm{~b}-\mathrm{d}$ & 107.45 a-f & $10.33 \mathrm{ab}$ \\
\hline & & 7.5 & $6.44 \mathrm{~b}-\mathrm{d}$ & $52.45 \mathrm{~d}-\mathrm{f}$ & $9.81 \mathrm{ab}$ \\
\hline & \multirow{3}{*}{8} & 0 & $4.76 \mathrm{~d}$ & $79.53 \mathrm{a}-\mathrm{f}$ & $14.912 \mathrm{a}$ \\
\hline & & 5 & $6.32 \mathrm{~b}-\mathrm{d}$ & $143.82 \mathrm{a}-\mathrm{c}$ & $10.32 \mathrm{ab}$ \\
\hline \multirow{10}{*}{6} & & 7.5 & $4.99 \mathrm{~cd}$ & $75.63 \mathrm{~b}-\mathrm{f}$ & $8.61 \mathrm{ab}$ \\
\hline & \multirow{3}{*}{0} & 0 & $7.4 \mathrm{a}-\mathrm{c}$ & $75.21 \mathrm{~b}-\mathrm{f}$ & $15.32 \mathrm{a}$ \\
\hline & & 5 & $5.11 \mathrm{~cd}$ & 117.6 a-d & $8.54 \mathrm{ab}$ \\
\hline & & 7.5 & $6.26 \mathrm{~b}-\mathrm{d}$ & 107.78 a-f & $13.16 \mathrm{ab}$ \\
\hline & \multirow{3}{*}{4} & 0 & $4.76 \mathrm{~d}$ & $31.3 \mathrm{f}$ & $13.49 \mathrm{ab}$ \\
\hline & & 5 & $6.32 \mathrm{~b}-\mathrm{d}$ & $76.14 b-f$ & $10.87 \mathrm{ab}$ \\
\hline & & 7.5 & $4.99 \mathrm{~cd}$ & $32.91 \mathrm{ef}$ & $10.33 \mathrm{ab}$ \\
\hline & \multirow{3}{*}{8} & 0 & $5.1 \mathrm{~cd}$ & $31.3 \mathrm{f}$ & $8.61 \mathrm{ab}$ \\
\hline & & 5 & $5.71 \mathrm{~b}-\mathrm{d}$ & $43.15 \mathrm{~d}-\mathrm{f}$ & $13.32 \mathrm{ab}$ \\
\hline & & 7.5 & $6.09 \mathrm{~b}-\mathrm{d}$ & 82.06 a-f & $8.54 \mathrm{ab}$ \\
\hline
\end{tabular}

\subsection{CAT and APX activities}

The results indicated that the interaction among the three factors were significant for both enzymes. Also, results showed that the highest CAT and APX activity (156.85 and $15.32 \mathrm{unit} / \mathrm{mg}$ protein, respectively) were achieved at 4 and $6 \mathrm{dS} \mathrm{m}^{-1}$ salinity with $0 \mathrm{mM}$ of Si and $0 \mu \mathrm{M}$ MeJA, respectively (Table 4). According to the results, the CAT activity was increased by salinity stress, however, the average values of the enzyme at moderate salinity level was more than the other levels. The APX activity was increased by increasing salinity levels from 0 to $6 \mathrm{dS} \mathrm{m}^{-1}$. The results of the present study revealed that salinity stress increased CAT and APX activities. Environmental stresses such as salinity and drought led to an increase in the antioxidant enzyme activity. There are many reports which indicated that the salinity stress enhanced POD and APX activities in different plants such as cucumber (Xie et al 2008), tomato (Srinieng et al 2015), Kentucky bluegrass (Puyang et al 2015), wheatgrass (Sheikh-Mohamadi et al 2017, 2018). CAT and APX are two main hydrogen peroxidescavenging enzymes in the plants, which transformed the overproduction of $\mathrm{H}_{2} \mathrm{O}_{2}$ induced by salinity stress to $\mathrm{H}_{2} \mathrm{O}$ and $\mathrm{O}_{2}$ (Ashraf et al 2019). Salinity stress led to a reduction in the activity of these enzymes, but their activities were restored in the presence of the $\mathrm{Si}$ and MeJA. It seems that $\mathrm{Si}$ and MeJA mitigated the adverse effects of salinity stress by reducing the $\mathrm{H}_{2} \mathrm{O}_{2}$ production. Si can reduce the malondialdehyde concentration under salinity stress, which can be attributed to its antioxidant role in the plant defense system (Kim et al 2017). 


\section{Conclusion}

The present study displayed that the increase in salinity level reduced chlorophyll index and fluorescence while vitamin $\mathrm{C}, \mathrm{CAT}$ and APX activities were increased. MeJA and Si enhanced the chlorophyll index and vitamin C at different salinity levels, respectively. However, CAT and APX decreased when the salinized plants were treated with MeJA and $\mathrm{Si}$. MeJA and Si may act to mitigate the adverse effects of salinity stress by reducing the $\mathrm{H}_{2} \mathrm{O}_{2}$ production. Finally, it can be concluded that MeJA and Si partially offset the adverse impacts of salinity stress.

\section{References}

Akbari M, Farajpour M, Aalifar M \& Sadat Hosseini M (2018). Gamma irradiation affects the total phenol, anthocyanin and antioxidant properties in three different persian pistachio nuts. Natural Product Research, 32(3): 322-326

Al-aghabary K, Zhu Z \& Shi Q (2005). Influence of silicon supply on chlorophyll content, chlorophyll fluorescence, and antioxidative enzyme activities in tomato plants under salt stress. Journal of Plant Nutrition, 27(12): 2101-2115

Ashraf M A, Riaz M, Arif M S, Rasheed R, Iqbal M, Hussain I \& Salman M (2019). The Role of Non-Enzymatic Antioxidants in Improving Abiotic Stress Tolerance in Plants. In M Hasanuzzaman, M Fujita, H Oku \& M T Islam (Eds.), Plant Tolerance to Environmental Stress: Role of Phytoprotectants, CRC Press, Boca Raton, pp. 468

Babst B A, Ferrieri R A, Gray D W, Lerdau M, Schlyer D J, Schueller M, Thorpe M R \& Orians C M (2005). Jasmonic acid induces rapid changes in carbon transport and partitioning in Populus. New Phytologist, 167(1): 63-72

Behzadifar M, Chehrazi M \& Aboutalebi A (2013). Effect of salt stress by using unconventional water on some morphological characters and ajmalicine alkaloid amount in the roots of Catharanthus roseus Cvs. Rosea and Alba. Annals of Biological Research, 4(8): 229-231

Boroomand N, Sadat-Hosseini M, Moghbeli M \& Farajpour M (2018). Phytochemical components, total phenol and mineral contents and antioxidant activity of six major medicinal plants from Rayen, Iran. Natural Product Research, 32(5): 564-567

Catalkaya G \& Kahveci D (2019). Optimization of Enzyme Assisted Extraction of Lycopene from Industrial Tomato Waste. Separation and Purification Technology

Chen C, Lu S, Chen Y, Wang Z, Niu Y \& Guo Z (2009). A gamma-ray-induced dwarf mutant from seeded bermudagrass and its physiological responses to drought stress. Journal of the American Society for Horticultural Science, 134(1): 22-30

Choudhari S M \& Ananthanarayan L (2007). Enzyme aided extraction of lycopene from tomato tissues. Food Chemistry, 102(1): 77 81

Choudhary R, Bowser T, Weckler P, Maness N \& McGlynn W (2009). Rapid estimation of lycopene concentration in watermelon and tomato puree by fiber optic visible reflectance spectroscopy. Postharvest Biology and Technology, 52(1): 103-109

Cuartero J \& Fernández-Muñoz R (1998). Tomato and salinity. Scientia Horticulturae, 78(1-4): 83-125

Czerpak R, Piotrowska A \& Szulecka K (2006). Jasmonic acid affects changes in the growth and some components content in alga Chlorella vulgaris. Acta Physiologiae Plantarum, 28(3): 195-203

Enteshari S \& Jafari T (2013). The effects of methyl jasmonate and salinity on germination and seedling growth in Ocimum basilicum L. Plant Physiology, 3(3): 749-756

Fontes P C R, Loures J L, Galvão J, Cardoso A A \& Mantovani E C (2004). Produção e qualidade do tomate produzido em substrato, no campo e em ambiente protegido. Horticultura Brasileira, 22(3): 614-619

Fugate K K, Lafta A M, Eide J D, Li G, Lulai E C, Olson L L, Deckard E L, Khan M F \& Finger F L (2018). Methyl jasmonate alleviates drought stress in young sugar beet (Beta vulgaris L.) plants. Journal of Agronomy and Crop Science, 204(6): 566-576

Haghighi M \& Pessarakli M (2013). Influence of silicon and nano-silicon on salinity tolerance of cherry tomatoes (Solanum lycopersicum L.) at early growth stage. Scientia Horticulturae, 161: 111-117

Hao X, Shi M, Cui L, Xu C, Zhang Y \& Kai G (2015). Effects of methyl jasmonate and salicylic acid on tanshinone production and biosynthetic gene expression in transgenic Salvia miltiorrhiza hairy roots. Biotechnology and Applied Biochemistry, 62(1): 24-31 
Kardoni F, Mosavi S J S, Parande S \& Torbaghan M E (2013). Effect of salinity stress and silicon application on yield and component yield offaba bean (Viciafaba). International Journal of Agriculture and Crop Sciences, 6(12): 814

Kim Y-H, Khan A L, Waqas M \& Lee I-J (2017). Silicon regulates antioxidant activities of crop plants under abiotic-induced oxidative stress: a review. Frontiers in Plant Science, 8: 510

Lee S, Sohn E, Hamayun M, Yoon J \& Lee I (2010). Effect of silicon on growth and salinity stress of soybean plant grown under hydroponic system. Agroforestry Systems, 80(3): 333-340

Losvik A, Glinwood R \& Jonsson L (2018). Effects of treatments of barley with methyl salicylate, methyl jasmonate or (Z)-3-hexen1-ol on barley gene expression and fecundity of bird cherry-oat aphid.

Maggio A, Raimondi G, Martino A \& De Pascale S (2007). Salt stress response in tomato beyond the salinity tolerance threshold. Environmental and Experimental Botany, 59(3): 276-282

Manan A, Ayyub C M, Pervez M A \& Ahmad R (2016). Methyl Jasmonate Brings About Resistance against Salinity Stressed Tomato Plants by Altering Biochemical and Physiological Processes. Pakistan Journal of Agricultural Sciences, 53(1): 35-41

Marodin J C, Resende J T, Morales R G, Faria M V, Trevisam A R, Figueiredo A S \& Dias D M (2016). Tomato post-harvest durability and physicochemical quality depending on silicon sources and doses. Horticultura Brasileira, 34(3): 361-366

Maxwell K \& Johnson G N (2000). Chlorophyll fluorescence-a practical guide. Journal of Experimental Botany, 51(345): 659-668

Mazorra L M, Nunez M, Hechavarria M, Coll F \& Sánchez-Blanco M J (2002). Influence of brassinosteroids on antioxidant enzymes activity in tomato under different temperatures. Biologia Plantarum, 45(4): 593-596

Morales F, Abadía A, Gómez-Aparisi J \& Abadía J (1992). Effects of combined $\mathrm{NaCl}$ and $\mathrm{CaCl} 2$ salinity on photosynthetic parameters of barley grown in nutrient solution. Physiologia Plantarum, 86(3): 419-426

Mosavi M, Khorshidi M, Masoudian N \& Hokmabadi H (2018). Study of some physiological characteristics of potato tissue under salinity stress. International Journal of Farming and Allied Sciences, 7(1): 1-5

Panhwar M, Keerio M \& Robert M (2017). Evaluating changes in wheat genotypes caused by hydrogen peroxide during seed treatment and their involvement in salt tolerance. Pakistan Journal of Agriculture, Agricultural Engineering and Veterinary Sciences, 33(1): 23-36

Pascale S D, Maggio A, Fogliano V, Ambrosino P \& Ritieni A (2001). Irrigation with saline water improves carotenoids content and antioxidant activity of tomato. The Journal of Horticultural Science and Biotechnology, 76(4): 447-453

Puyang X, An M, Han L \& Zhang X (2015). Protective effect of spermidine on salt stress induced oxidative damage in two Kentucky bluegrass (Poa pratensis L.) cultivars. Ecotoxicology and Environmental Safety, 117: 96-106

Qiu Z, Guo J, Zhu A, Zhang L \& Zhang M (2014). Exogenous jasmonic acid can enhance tolerance of wheat seedlings to salt stress. Ecotoxicology and Environmental Safety, 104: 202-208

Reinbothe S, Mollenhauer B \& Reinbothe C (1994). JIPs and RIPs: the regulation of plant gene expression by jasmonates in response to environmental cues and pathogens. The Plant Cell, 6(9): 1197

Rochaix J-D (2011). Assembly of the photosynthetic apparatus. Plant Physiology, 155(4): 1493-1500

Sheikh-Mohamadi M-H, Etemadi N, Nikbakht A, Farajpour M, Arab M \& Majidi M M (2017). Screening and selection of twenty Iranian wheatgrass genotypes for tolerance to salinity stress during seed germination and seedling growth stage. HortScience, 52(8): $1125-1134$

Sheikh-Mohamadi M-H, Etemadi N, Nikbakht A, Farajpour M, Arab M \& Majidi M M (2018). Wheatgrass germination and seedling growth under osmotic stress. Agronomy Journal

Sheikh Beig Goharrizi M, Dejahang A, Tohidfar M, Izadi Darbandi A, Carrillo N J, Hajirezaei M \& Vahdati K (2016). Agrobacterium mediated transformation of somatic embryos of Persian walnut using fld gene for osmotic stress tolerance. Journal of Agricultural Science and Technology, 18: 423-435

Soylemezoglu G, Demir K, Inal A \& Gunes A (2009). Effect of silicon on antioxidant and stomatal response of two grapevine (Vitis vinifera L.) rootstocks grown in boron toxic, saline and boron toxic-saline soil. Scientia Horticulturae, 123(2): 240-246 
Srinieng K, Saisavoey T \& Karnchanatat A (2015). Effect of salinity stress on antioxidative enzyme activities in tomato cultured in vitro. Pakistan Journal of Botany, 47(1): 1-10

Stamatakis A, Papadantonakis N, Savvas D, Lydakis-Simantiris N \& Kefalas P (2003). Effects of silicon and salinity on fruit yield and quality of tomato grown hydroponically. In: International Symposium on Managing Greenhouse Crops in Saline Environment 609

Suntornsuk L, Gritsanapun W, Nilkamhank S \& Paochom A (2002). Quantitation of vitamin C content in herbal juice using direct titration. Journal of Pharmaceutical and Biomedical Analysis, 28(5): 849-855

Ueda J \& Saniewski M (2006). Methyl jasmonate-induced stimulation of chlorophyll formation in the basal part of tulip bulbs kept under natural light conditions. Journal of fruit and ornamental plant research, 14: 199

Wang Y, Gao L, Wang Q \& Zuo J (2019). Low temperature conditioning combined with methyl jasmonate can reduce chilling injury in bell pepper. Scientia Horticulturae, 243: 434-439

Wickens T D \& Keppel G (2004). Design and analysis: A researcher's handbook. Pearson Prentice-Hall, New York

Wu Y, Liao W, Dawuda M M, Hu L \& Yu J (2019). 5-Aminolevulinic acid (ALA) biosynthetic and metabolic pathways and its role in higher plants: a review. Plant Growth Regulation, 87(2): 357-374

Xie Z, Duan L, Tian X, Wang B, Eneji A E \& Li Z (2008). Coronatine alleviates salinity stress in cotton by improving the antioxidative defense system and radical-scavenging activity. Journal of Plant Physiology, 165(4): 375-384

Yoon J Y, Hamayun M, Lee S-K \& Lee I-J (2009). Methyl jasmonate alleviated salinity stress in soybean. Journal of Crop Science and Biotechnology, 12(2): 63-68

Zhu Y \& Gong H (2014). Beneficial effects of silicon on salt and drought tolerance in plants. Agronomy for Sustainable Development, 34(2): 455-472 